\title{
Composition of High Fission Product Wastes Resulting from Future Reprocessing of Commercial Nuclear Fuels
}

July 1986

Prepared for the U.S. Department of Energy under Contract DE-AC06-76RLO 1830

Pacific Northwest Laboratory Operated for the U.S. Department of Energy Battelle Memorial Institute 


\title{
DISCLAIMER
}

This report was prepared as an account of work sponsored by an agency of the United States Government. Neither the United States Government nor any agency thereof, nor any of their employees, makes any warranty, express or implied, or assumes any legal liability or responsibility for the accuracy, completeness, or usefuiness of any information, apparatus, product, or process disclosed, or represents that its use would not infringe privately owned rights. Reference herein to any specific commercial product, process, or service by trade name, trademark, manufacturer, or otherwise, does not necessarily constitute or imply its endorsement, recommendation, or favoring by the United States Government or any agency thereof. The views and opinions of authors expressed herein do not necessarily state or reflect those of the United States Government or any agency thereof.

\author{
PACIFIC NORTHWEST LABORATORY \\ operated by \\ BATTELLE \\ for the \\ UNITED STATES DEPARTMENT OF ENERGY \\ under Contract DE-AC06-76RLO 1830
}

\begin{tabular}{|c|c|}
\hline \multicolumn{2}{|c|}{ Printed in the United States of America } \\
\hline \multirow{2}{*}{\multicolumn{2}{|c|}{$\begin{array}{l}\text { Available from } \\
\text { National Technical Information Service }\end{array}$}} \\
\hline \multirow{4}{*}{\multicolumn{2}{|c|}{$\begin{array}{c}\text { United States Department of Commerce } \\
5285 \text { Port Royal Road } \\
\text { Springfield, Virginia } 22161\end{array}$}} \\
\hline & \\
\hline & \\
\hline & \\
\hline \multirow{2}{*}{\multicolumn{2}{|c|}{$\begin{array}{l}\text { NTIS Price Codes } \\
\text { Microfiche A01 }\end{array}$}} \\
\hline & \\
\hline \multicolumn{2}{|c|}{ Printed Copy } \\
\hline & Price \\
\hline Pages & Codes \\
\hline $001-025$ & $\mathrm{~A} 02$ \\
\hline $026-050$ & $\mathrm{A03}$ \\
\hline 051-075 & $\mathrm{A} 04$ \\
\hline $076-100$ & A05 \\
\hline $107-125$ & A06 \\
\hline $126-150$ & $\wedge 07$ \\
\hline $151-175$ & $A 0 B$ \\
\hline $176-200$ & $\mathrm{~A} 09$ \\
\hline $201-225$ & A010 \\
\hline $226-250$ & A011 \\
\hline $251-275$ & A012 \\
\hline $276-300$ & A013 \\
\hline
\end{tabular}


COMPOSITION OF HIGH FISSION PRODUCT WASTES RESULTING FRDM FUTURE REPROCESSING OF COMMERCIAL NUCLEAR FUELS

J. L. Swanson

JuTy 1986

Prepared for the U.S. Department of Energy under Contract DE-ACO6-76RLD 1830

Pacific Northwest Laboratory Richland, Washington 99352 
Pacific Northwest Laboratory studies, aimed at defining appropriate glass compositions for future disposal of high-level wastes, have developed composition ranges for the waste that will likely result during reprocessing of Light water Reactor (LWR) and Liquid Metal Reactor (LMR) fuels. The purpose of these studies was to provide baseline waste characterizations for possible future commercial high-level waste so that waste immobilization technologies (e. g. vitrification) can be studied.

Ranges in waste composition are emphasized because the waste will vary with time as different fuels are reprocessed, because choice of process chemicals is unclear, and because fuel burnups will vary. Consequently, composition ranges are based on trends in fuel reprocessing procedures and on achievable burnups in operating reactors.

In addition to the fission product and actinide elements, which are the primary hazardous materials in the waste, likely composition ranges are given for inert elements that may be present in the waste. These other elenents may be present because of being present in the fuel, because of being added as process chemicals during reprocessing, because of being added during equipment decontamination, or because of corrosion of plant equipment and/or fuel element cladding.

This report includes a discussion of the chemicals added in variations of the PUREX process, which is likely to remain the favored reprocessing technique for commercial nuclear fuels. Consideration is also given to a pyrochemical process proposed for the reprocessing of some LMR fuels. 


\section{ACKNOWLEDGMENTS}

Discussions with D. 0. Campbell of Oak Ridge National Laboratory were very helpfut, especially as regards reprocessing trends in foreign countries. L. A. Bray of Pacific Northwest Laboratory provided valuable technical review.

The report was typed by K. M. McCormack and L. D. Maki and was edited by N. M. Sherer. 


\section{CONTENTS}

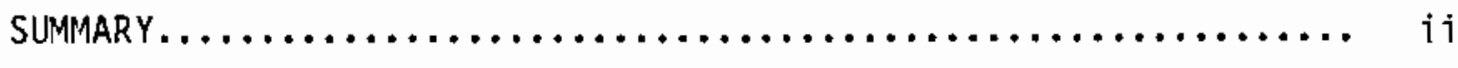

ACKNOWLEDGMENTS $\ldots \ldots \ldots \ldots \ldots \ldots \ldots \ldots \ldots \ldots \ldots \ldots \ldots \ldots \ldots \ldots \ldots \ldots \ldots \ldots$

INTROOUCTION................................. I

HIGH-LEVEL WASTE COMPOSITION RANGES FROM

REPROCESSING OF LWR AND LMR FUELS .................. 6

WASTE FROM REPROCESSING OF LWR FUEL................ 8

WASTE FROM REPROCESSING OF LMR FUEL................ 18

Wastes from Conventional LMR Fuel Reprocessing........ 19

Waste from Pyrochemical LMR Fuel Reprocessing......... 28

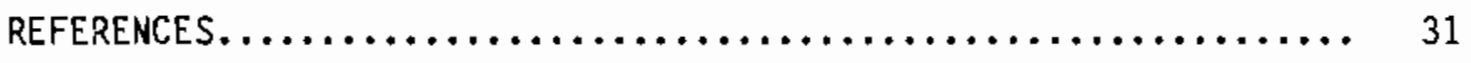


FIGURES

1 Simplified Flow Diagrams Comparing Process Chemical Additions in Three Commercial Reprocessing Flowsheets......... 3

TABLES

1 Comparison of Likely Composition Ranges in High-Level Wastes from Reprocessing LWR and LMR Fuels.............. 7

2 Fission Product and Actinide Contents, ReTative to Cesium, of LWR Fuels............................. g

3 Composition Ranges Likely in High-Level Liquid Wastes from Future Reprocessing of LWR Fuel.................... 11

4 Illustrations of Potential Gadolinium Contents of

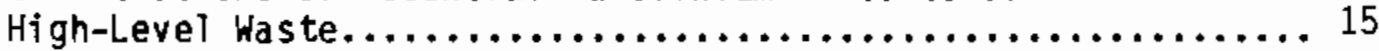

5 Fractions of Fission Products in Dissolver Residue

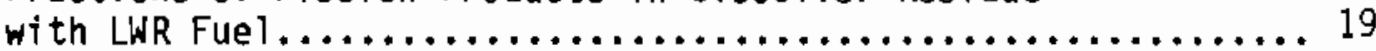

6 Fission Product and Actinide Contents, Relative to Cesium, of LMR Fuels.............................. 21

7 Composition Ranges Likely in High-Level Liquid Wastes from Future Conventional Reprocessing of LMR Fue1........... 22

8 Stainless Steel Contents of LMR Fuel Elements............. 26

9 Fractions of Fission Products in Dissolver Residue with

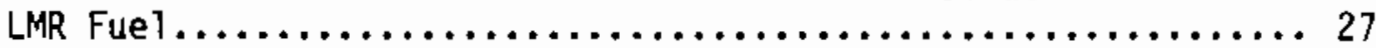

10 Approximate Composition of Pyrohydrolyzed Sa 7 ts from Pyrochemical Reprocessing........................... 30 


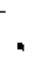

.

. 


\section{INTRODUCTION}

Al though the current plan in the United States for disposition of the spent fuel elements from commercial LWR nuclear power plants is to dispose of them (without treatment) in a geologic repository, future plans may include reprocessing of such fuels to recover their contained values. Reprocessing will be needed if breeder nuclear power plants are to be employed. It will be needed to provide the plutonium (from LWR fuel) for use in the initial breeder fuel as well as to recycle the breeder fuel. The wastes resulting from such commercial reprocessing activities would then be prepared for suitable disposal. The purpose of the work reported here was to provide baseline characterizations of such wastes so that waste immobilization technologies (e.g. vitrification) can be studied.

The high-level waste ( $\mathrm{HLW}$ ) resulting from conventional fuel reprocessing contains, with some exceptions, essentially all of the radioactive isotopes present in the spent fuel. The exceptions are uranium and plutonium lonly $1 \%$ or less remains in the high-level waste stream), volatile fission products, and the activation products formed in the fuel cladding and assembly hardware. This waste is in the form of a nitrate solution, which must be treated before it can be disposed of. The preferred approach for treating this liquid waste is to vitrify it (convert it to a qlass).

The preferred reprocessing technique throughout the world for the last 30 years or so, and for the foreseeable future, is the so-called PUREX process. In this process the fuel core is first exposed by chenical decladding or by mechanical means and is then dissolved in nitric acid. The resultant solution of uranium, plutonium, and fission product nitrates is then mixed, in a suitable contactor, with an organic solvent containing tributyl phosphate (TBP). Uranium and plutonium are more extractable than the fission products and, by suitable adjustment of conditions, are highly purified from them. Uranium and plutonium are al so separated froln each other by adjustment of conditions; these adjustments generally involve addition of a reducing agent to convert plutonium from the extractable tetravalent form [Pu(IV)] to the inextractable trivalent form [PU(III)]. The TBP-containing solvent is washed after each cycle to remove undesirable degradation products, and is then reused. 
Wi thin the general PUREX process concept described above, there is a large number of possible variations that can be used to obtain the desired result. Consequently, there is no one "PUREX process." It is probably safe to say that, of all the plants in the world employing the "PUREX process," no two of then run truly identical processes.

Simplified flow diagrams of three commercial fuel reprocessing plant designs, all employing a PUREX process, are compared in Figure 1 to illustrate how different operational philosophies can affect the composition of the resulting high-level waste and to show how commercial fuel reprocessing flowsheets have progressed through the years. Added materials that will contribute to the HLW composition are marked with an asterisk for emphasis.

The upper diagram represents the process used during the operation of the Nuclear Fuels Services (NFS) plant at West Valley, New York. This process added large quantities of iron to the waste, by using dissolvable iron basket liners to contain chopped fuel during transport from the shear to the dissolver, and by using ferrous sulfamate as the reducing agent to effect separation of the uranium and the plutonium. The use of ferrous sulfamate al so results in the addition of sulfate, formed by sulfamate hydrolysis, to the waste. The process used at NFS al so resulted in addition of large quantities of sodium to the waste. Sodium was added: 1) as sodium hydroxide in some decontamination solutions, 2) as sodium hydroxide to neutralize the waste so that it could be stored in mild steel tanks, 3) as sodium nitrite solution to reoxidize $\mathrm{Pu}$ (III) to $\mathrm{Pu}$ (IV) for final purification solvent extraction cycles, and, 4) as sodium carbonate solution to wash the used solvent before it is reused. Except for the use of dissolvable iron basket liners, the NFS process was very similar to those used in the PUREX plants at Hanford and Savannah River, where fuels irradiated to produce weapons-grade plutoni um are reprocessed.

The HLW generated during operation of the NFS plant has been stored awaiting selection and development of suitable treatment processes. It is now planned to treat these wastes to produce low-level and high-level fractions. The high-level fraction will be vitrified. 

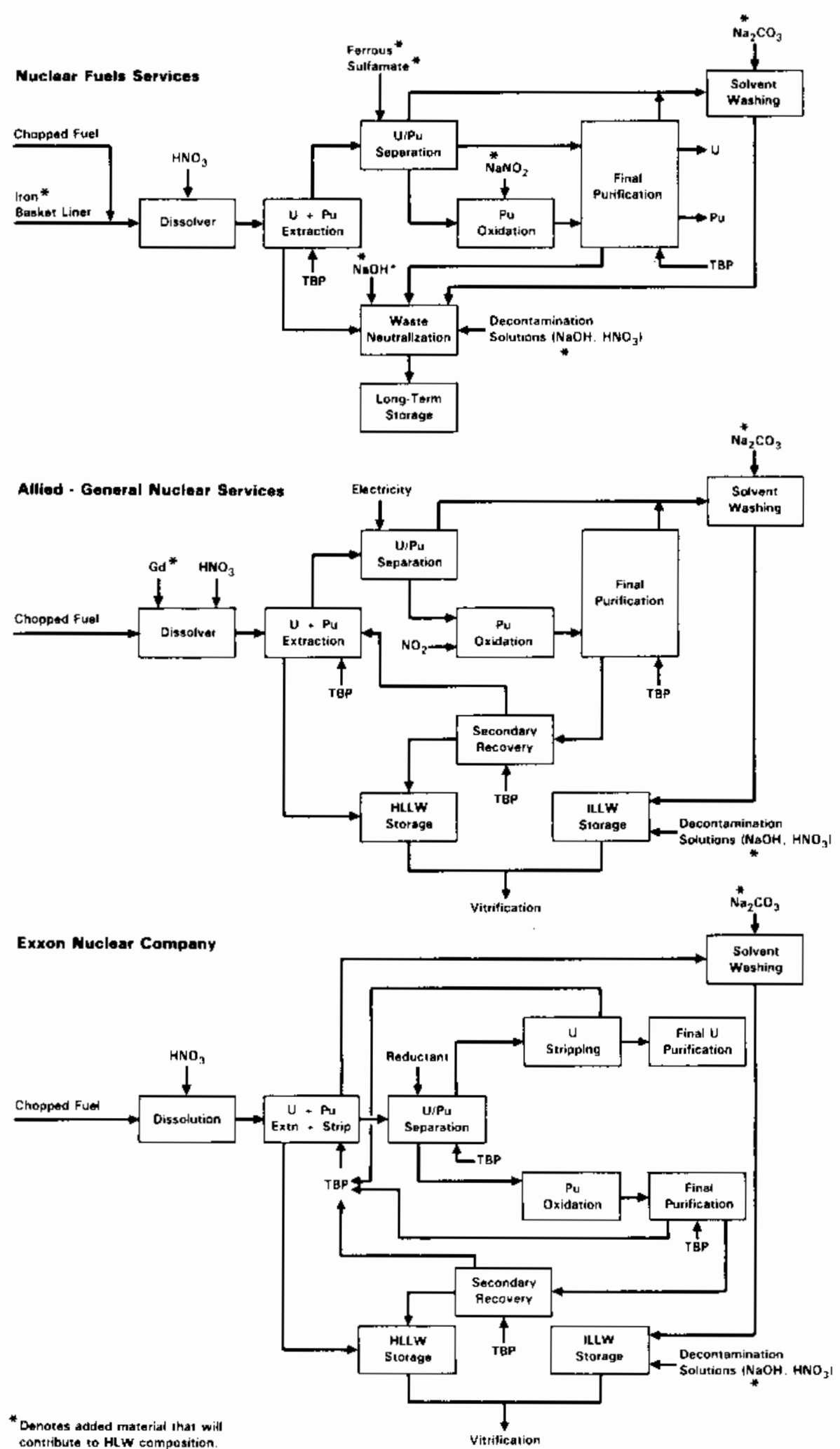

FIGURE 1. Simplified Flow Diagrams Comparing Process Chemical Additions in Three Commercia] Reprocessing Flowsheets 
The middle flow diagram of Figure 1 depicts the process designed for use in the Allied-General Nuclear Services (AGNS) plant at Barnwel1, South Carolina. This plant was built but never operated because of changes in the political and economic climates. This process eliminated the addition of iron by avoiding the use of dissolvable basket liners and by avoiding the use of ferrous sulfamate as a plutonium reductant. Instead of ferrous sulfamate, an electrolytic reduction process was to be used for the initial separation of uranium and plutonium and a salt-free chemical reductant (hydroxylamine nitrate) was planned for final separation. This process al so greatly reduced the addition of sodium by avoiding waste neutralization (wastes were to be stored in stainless steel tanks, so they could remain acidic) and by using $\mathrm{NO}_{2}$ gas instead of $\mathrm{NaNO}_{2}$ solution for plutonium reoxidation. However, this process was designed to employ gadolinium as a soluble neutron poison to maintain criticality control in the dissolvers. Adding this material in the quantities indicated at that time would have resul ted in a significant increase in the minimum possible quantity of high-level waste glass.

The bottom flow diagram of Figure 1 represents the process developed for the proposed Exxon Nuclear Company plant. Plans for this plant were teminated before construction began. This design continued the trend towards cleaner high-level waste compositions. It not orly avoided the addition of iron and minimized the addition of sodium, as AGNS had, but it al so avoided the addition of gadolinium by using a different dissolver design.

As illustrated by the foregoing discussion, the clear trend in the development of PUREX processes for reprocessing commercial reactor fuels has been to minimize the use of process chemicals that add salts to the high-level waste. This has been done in an effort to reduce the volume of high-level waste glass to be prepared and disposed of and thus to increase the cost effectiveness of the overall fue 1 reprocessing/waste management system. However, it now appears that these efforts may have been overly diligent in two areas: 1) the over-minimization of sodium usage, and 2) the achieving of high fission product loadings in high-level waste glasses.

Both the AGNS and Exxon processes depicted in Figure 1 involve the use of sodium salts to wash the solvent, and in some equipment and facility 
decontamination solutions. The quantities of sodium thus introduced into the waste were estimated to be less than the quantities required in the formulation of suitable borosilicate waste glasses. Thus, the sodiumcontaining intermediate-level liquid waste (ILLW) stream could be mixed with the high-level liquid waste (HLLW) stream and vitrified with no increase in the quantity of HLW glass. In spite of the apparent practicability of such an approach, research and development of solvent washing procedures that avoid the use of sodium salts has continued, as summarized recently by Mailen and Tallent (1984).

The achieving of high fission product loadings in HLW glass does reduce the minimum amount of HLW glass that must be produced, but other factors may determine that the minimum amount of glass does not provide the most cost effective waste disposal system. This is because of the complex heat dissipation factors that govern the disposal of heat-generating waste in geologic repositories. This picture is complicated by the fact that the heat dissipation properties of various candidate repository media are different, so that the optimum concentration of fission products in HLW glass will depend on factors such as the repository medium and the waste emplacement technique. Mckee et al. (1983) have addressed these factors for a basalt repository and found that, for certain conditions, the maximum fission product loading is undesi rable. 


\section{HIGH-LEVEL WASTE COMPOSITION RANGES FROM REPROCESSING OF}

LWR AND LMR FUELS

Composition ranges likely to occur in high-level wastes (HLK) from the future reprocessing of commercial nuclear fuels were developed based on trends in fuel reprocessing procedures and in achievable fuel burnups. This was done to provide a sound basis for studies afmed at defining appropriate glass compositions for the safe disposal of such wastes. Considerations involved in nuclear waste glass composition development have been summarized by Chick, Swanson, and Goldman (1984).

The PUREX process is likely to remain the favored reprocessing technique for such fuels. Brief consideration was also given to a pyrochemical process proposed for reprocessing some fuels.

High-level liquid waste (HLLW) composition ranges were developed for the reprocessing of both Light Water Reactor (LWR) and Liquid Meta1 Reactor (LMR) fuels. These are summarized in Table 1, and discussed in more detail in the following sections. The LWR fuel values are based on burnups in the range of 20,000 to 50,000 megawatt-days per metric ton of uranium (MWd/MTU). The LMR fuel values are based on mixed processing of core and blanket fuels and a core fuel burnup of 100,000 megawatt-days per metric ton of heavy metal (MWd/MTHM).

The compositions given in Table 1 should be representative of HLW resulting from future reprocessing activities in other countries, as well as in the United States. Radioactive components will be comparable because they are governed by the laws of nature. Nonradioactive components will be comparable because the PUREX process, with minimal addition of materials that will contribute to waste composition and volume, is the reprocessing technique favored in all countries. This should not be taken to mean that all HLW compositions will be identical. Variations will exist because of differing operational philosophies, both within and between countries, but such variations should fall within the ranges given in Table 1.

The first 24 elements 1 isted in Table 1 are fission products that are produced during reactor operation. The next 5 elements are the actinide elements that are used in the fuel initially or are formed during reactor 
TABLE 1. Comparison of Likely Composition Ranges in HighLevel Wastes from Reprocessing LWR and LMR Fuels

$\frac{\text { Element }}{\mathrm{Se}}$

$\mathrm{Rb}$

Sr

$\mathrm{Yr}(\mathrm{c})$

$\mathrm{Zr}$ (c)

Tc (c)

$\mathrm{Ru}(\mathrm{c})$

$\mathrm{Rh}(\mathrm{c})$

$P_{d}(c)$

$\mathrm{Ag}(\mathrm{C})$

Cd

Sn

Te

Cs

Ba

La

$\mathrm{Ce}$

$\operatorname{Pr}$

Nd

Pm

Sm

Eu

Gd

U

Np

$\mathrm{Pu}$

$\mathrm{Am}+\mathrm{Cm}$

Gd

$\mathrm{Na}$

$\mathrm{Mn}$

$\mathrm{Fe}$

$\mathrm{Cr}$

$\mathrm{Ni}$

$\mathrm{P}$

$F$

Al

\section{$g$ El ement/g Cs}

HLLW froip a)
LWR Fue $(\mathrm{a})$
0.0206

0.126

0.320

0.168

1.20

1.10

0.256

0.555

0.123

0.425

0.006

0.039

0.032

0.172

1.000

0.522

0.447

0.924

0.411

1.421

0.0428

0.279

0.0567

0.0313

$0.5-5.7$

0.158

$0.007-0.035$

0.072

\section{$0-5$}

1. 4-10.2

$0.020-0.20$

$0.034-0.34$

$0.0092-0.092$

$0.0048-0.048$

$0.072-0.72$

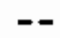

LMR Fue] $(b)$

0.0107

0.0548

0.124

0.065

0.668

0.322

0.0416

0.0806

0.0232

0.498

0.047

0.074

0.078

0.174

1.000

0.364

0.304

0.531

0.282

0.887

0.0495

0.258

0.0338

0.0285

$0.3-1.5$

0.0463

$0.035-0.18$

0.320

$0-0.3$

$1.0-3.3$

$0.014-0.058$

$0.078-0.67$

$0.022-0.19$

$0.011-0.096$

$0.052-0.21$

$0-0.003$

$0-0.014$

(a) To convert to g/MTHM, mul tiply by (MWd/MTHM) and by $(0.0825 \mathrm{~g} \mathrm{Cs} / \mathrm{MWd})$.

(b) To convert to g/MTHM, muttiply by (MWd/MTHM) and by $(0.11 \mathrm{~g} \mathrm{Cs} / \mathrm{MWd})$.

(c) Portions of these fission products remain as undissolved solids that are not included in HLLW. 
operation. These 29 elements comprise the bulk of the materials that make the waste hazardous and necessitate its careful handling and disposal.

The last 9 elements 1 isted in Table 1 are inert components that may be introduced into the waste during reprocessing. Gadolinium may be used as a soluble neutron poison in some reprocessing plant designs. Sodium-containing solutions will likely be used to wash the solvent and for decontaminating equipment and facilities. These solutions could be handled separately from the HLW but, since sodium is a necessary component of the preferred waste glasses, it is likely that they will be added to the HLW. Manganese is another likely component of decontamination solutions. Iron, chromium, and nickel enter the HLW as a result of equipment corrosion and, in the case of LMR fuels, as a result of partial dissolution of the stainless steel cladding. Phosphorus is present as a result of the tributyl phosphate extractant used in the PUREX process.

WASTE FROM REPROCESSING OF LWR FUEL

Light water reactor (LWR) fuels are composed of $\mathrm{UO}_{2}$ fuel pellets contained within tubes of zirconium alloy cladding. The individual tubes are held together in assemblies of tube bundles or clusters, using fuel hardware that is generally made from stainless steel or Inconel. The fuel is prepared for reprocessing by shearing or chopping it into short lengths to expose the $\mathrm{UO}_{2}$ core so that it can be dissolved out of the tubes with nitric acid.

The components of the HLW resulting from irradiated LWR fuel reprocessing can come from six different sources: 1) fission products and unrecovered transuranic elements; 2) losses of uranium and plutonium; 3) corrosion products; 4) soluble neutron poisons; 5) separations process chemicals; and 6) waste handling chemicals.

The fission product content of the HLW is governed solely by the burnup of the fuel for a given fuel cycle. As a first approximation, the quantity of most fission products is directly proportional to burnup, and varies only slightly between bolling water reactors (BWRs) and pressurized water reactors (PWRs). Data illustrating these facts are available in Croff and Alexander (1980). Table 2 contains some of these data, presented as (weight) ratios of other fission products to the weight of fission product cesium. 
TABLE 2. Fission Product and Actinide Contents, Relative to Cesium, of LWR Fuels

\begin{tabular}{lll} 
& PWR Fuel (a) & BWR Fuel (b) \\
\cline { 2 - 3 } $\mathrm{Se}$ & 0.0210 & 0.0203 \\
$\mathrm{Rb}$ & 0.128 & 0.124 \\
$\mathrm{Sr}$ & 0.326 & 0.314 \\
$\mathrm{Y}$ & 0.170 & 0.165 \\
$\mathrm{Zr}$ & 1.31 & 1.27 \\
$\mathrm{Mo}$ & 1.24 & 1.20 \\
$\mathrm{Tc}$ & 0.287 & 0.285 \\
$\mathrm{Ru}$ & 0.844 & 0.814 \\
$\mathrm{Rh}$ & 0.174 & 0.176 \\
$\mathrm{Pd}$ & 0.478 & 0.465 \\
$\mathrm{Ag}$ & 0.029 & 0.029 \\
$\mathrm{Cd}$ & 0.040 & 0.036 \\
$\mathrm{Sn}$ & 0.0335 & 0.0302 \\
$\mathrm{Te}$ & 0.176 & 0.171 \\
$\mathrm{Cs}$ & 1.000 & 1.000 \\
$\mathrm{Ba}$ & 0.530 & 0.517 \\
$\mathrm{La}$ & 0.453 & 0.441 \\
$\mathrm{Ce}$ & 0.942 & 0.907 \\
$\mathrm{Pr}$ & 0.416 & 0.406 \\
$\mathrm{Nd}$ & 1.44 & 1.40 \\
$\mathrm{Pm}$ & 0.0425 & 0.0430 \\
$\mathrm{Sm}$ & 0.282 & 0.276 \\
$\mathrm{Eu}$ & 0.059 & 0.055 \\
$\mathrm{Gd}$ & 0.033 & 0.029 \\
$\mathrm{Ud}$ & 356.3 & 0.150 \\
$\mathrm{~Np}$ & 0.165 & 3.67 \\
$\mathrm{Pu}$ & 3.39 & 0.072 \\
$\mathrm{Am}+\mathrm{Cm}$ & 0.072 &
\end{tabular}

(a) 33,000 MWd/MTU, l year c00ling. $0.0813 \mathrm{~g} \mathrm{Cs} / \mathrm{MWd}$. (b) $27,500 \mathrm{MHd} / \mathrm{MTU}$, 1 year cooling. $0.0837 \mathrm{~g} \mathrm{Cs} / \mathrm{MWd}$. 
The fractions of the uranium and plutonium that are lost to the waste can be reduced by improvenents in equipment and flowsheet design. The effect of these product losses on the amount of glass produced is primarily due to uranium because of the low quantity of plutonium in LWR fuel.

The quantities of corrosion products in the waste can be minimized by using better construction materials and by restricting the use of corrosive chemicals. They can also be reduced by minimizing the number of high temperature operations (e.g., by eliminating inter-cycle concentration steps).

Soluble neutron poisons (usually gadolinium) are used in some designs as part of the required nuclear criticality control. Other means of achieving the needed control are used in other designs; it is possible to design equipment so that soluble neutron poisons are not necessary.

Separations process chemicals are primarily those used to adjust and control Pu valence and those used to wash the solvent so that it can be reused. Examples of such chemicals that can affect the composition of the HLW glass are ferrous sulfamate, sulfamic acid, sodium nitrite, and sodium carbonate. Examples of other process chemicals that would not affect the composition of the HLW are hydroxylamine nitrate, hydrazine nitrate, nitrogen dioxide, and hydrazine carbonate.

Waste handling chemicals that add salts to HLW have been used extensively in wastes from reprocessing defense fuels but have been avoided in recent commercial fuel reprocessing concepts. This trend is expected to continue, so this source is not important in this study.

With consideration of these factors in mind, the HLW composition listed in Table 3 was developed for the reprocessing of LWR fuels. Composition ranges are emphasized, rather than a single composition, because of several factors. Among the more important of these factors are:

1) The likelihood that future reprocessing plants will have minimal surge storage capacity for liquid HLW. Thus, the HLW composition will vary with time as different fuels are reprocessed.

2) The lack of a clear choice as to whether a future commercial fuel plant will employ a soluble poison (Gd) for criticality control. 
TABLE 3. Composition Ranges Likely in High-Level Liquid Wastes from Future Reprocessing of LWR Fuel

\begin{tabular}{|c|c|c|}
\hline El ement & Source & $\underline{g}$ Element $/ g \mathrm{Cs}^{(h)}$ \\
\hline $\begin{array}{l}\text { Se } \\
R b \\
\text { Sr } \\
\text { Y } \\
\mathrm{Zr} \\
\text { Pdo } \\
\text { TC } \\
\text { Ru } \\
\text { Rh } \\
\text { Pd } \\
\text { Ag } \\
\text { Cd } \\
\text { Sn } \\
\text { Te } \\
\text { Cs } \\
\text { Ba } \\
\text { La } \\
\text { Ce } \\
\text { Pr } \\
\text { Nd } \\
\text { Pm } \\
\text { Sm } \\
\text { Eu } \\
\text { Gd } \\
\text { Added Gd } \\
\text { Total La-Gd }\end{array}$ & $\begin{array}{l}\text { (a) } \\
(a) \\
(a) \\
(a) \\
(a) \\
(a) \\
(a) \\
(a) \\
(a) \\
(a) \\
(a) \\
(a) \\
(a) \\
(a) \\
(a) \\
(a) \\
(a) \\
(a) \\
(a) \\
(a) \\
(a) \\
(a) \\
(a) \\
(b+c) \\
(a+b+c)\end{array}$ & $\begin{array}{l}0.0206 \\
0.126 \\
0.320 \\
0.168 \\
1.20(i) \\
1.10(i) \\
0.266(i) \\
0.555(i) \\
0.123(j) \\
0.425(i) \\
0.006(i) \\
0.039 \\
0.032 \\
0.172 \\
1.000 \\
0.522 \\
0.447 \\
0.924 \\
0.411 \\
1.421 \\
0.0428 \\
0.279 \\
0.0567 \\
0.0313 \\
0-5(j) \\
3.5-8.5\end{array}$ \\
\hline $\begin{array}{l}\text { U } \\
\mathrm{Np} \\
\mathrm{Pu} \\
\mathrm{Am}+\mathrm{Cm}\end{array}$ & $\begin{array}{l}\text { (d) } \\
\text { (e) } \\
\text { (d) } \\
\text { (e) }\end{array}$ & $\begin{array}{l}0.5-5.7(k) \\
0.158 \\
0.007-0.035(1) \\
0.072\end{array}$ \\
\hline $\begin{array}{l}\mathrm{Na} \\
\mathrm{Mn} \\
\mathrm{Fe} \\
\mathrm{Cr} \\
\mathrm{Ni}\end{array}$ & $\begin{array}{l}(c+f) \\
(f) \\
(g) \\
(g) \\
(g)\end{array}$ & $\begin{array}{l}1.4-10.2(\mathrm{~m}) \\
0.020-0.20(\mathrm{n}) \\
0.034-0.34(0) \\
0.0092-0.092(0) \\
0.0048-0.048(0)\end{array}$ \\
\hline$P$ & (c) & $0.072-0.72(p)$ \\
\hline
\end{tabular}




\section{Footnotes to Table 3}

(a) Fission product.

(b) Burnable poison in fuel.

(c) Flowsheet chemical.

(d) Waste loss.

(e) Unrecovered actinide.

(f) Decontamination chemicat.

(g) Corrosion product.

(h) To convert to g/MTU, multiply by (MWd/MTU burnup) and by $(0.0825 \mathrm{~g}$ Cs/Mwd). These fission product values are averages taken from PWR and BWR fuel data (Table 2).

(i) Based on the fractions undissolved given in the discussion (Table 5). These are 0.8 for $\mathrm{Ag}, 0.33$ for $\mathrm{Ru}, 0.30$ for $\mathrm{Rh}, 0.10$ for $\mathrm{Pd}$ and $\mathrm{Mo}$, and 0.07 for Tc and $\mathrm{Zr}$.

(j) Range addressed more fully in text and in Table 4.

(k) Low value is based on $0.2 \%$ waste 1 oss and $50,000 \mathrm{MWd} / \mathrm{MTU}$ burnup. High value is based on $1.0 \%$ waste loss and 20,000 14Wd/MTU burnup.

(1) Range is based on 0.2 to $1.0 \%$ waste 10 s.

(m) Low value is based on $50,000 \mathrm{MWd} / \mathrm{MTU}$ burnup with $3 \mathrm{~kg} \mathrm{Na} / \mathrm{MTU}$ from solvent washing and $3 \mathrm{~kg} \mathrm{Na} / \mathrm{MTU}$ from decontamination solutions. High value is based on 20,000 MWd/MTU burnup with $5 \mathrm{~kg} \mathrm{Na} / \mathrm{MTU}$ from solvent washing and $12 \mathrm{~kg} \mathrm{Na} / \mathrm{MTU}$ from decontamination solutions.

(n) Values based on $0.028 \mathrm{Mn} / \mathrm{g} \mathrm{Na}$ used in decontamination solutions. Low value is based on 50,000 MWd/MTU burnup with $3 \mathrm{~kg} \mathrm{Na} / \mathrm{MTU}$ from decontamination solutions, and high value is based on 20,000 MWd/MTU burnup with $12 \mathrm{~kg} \mathrm{Na} / \mathrm{MTU}$ from decontamination solutions.

(o) Low value is based on 50,000 MWd/MTU burnup with $0.15 \mathrm{~kg}$ corrosion products/MTU. High value is based on $20,000 \mathrm{MWd} / \mathrm{MTU}$ burnup with $0.60 \mathrm{~kg}$ corrosion products/MTU. Uniform corrosion of $304 \mathrm{~L}$ stainless steel is assumed.

(p) Low value is based on 50,000 MWd/MTU burnup with $0.3 \mathrm{~kg} \mathrm{P} / \mathrm{MTU}$. High value is based on $20,000 \mathrm{MWd} / \mathrm{MTU}$ burnup with $1.2 \mathrm{~kg} \mathrm{P} / \mathrm{MTU}$. 
3) The fact that fuel burnups ranging from 20,000 to 50,000 MWd/MTU are probable.

4) The fact that fuels designed for high burnups will likely contain a burnable poison (Gd).

Certain components present in large amounts in existing (West Valley) waste will be absent, or greatly reduced in concentration, from future LWR fuel wastes. Notable among these are sulfate, which will be absent; iron, which will be present only because of equipment corrosion; and sodium, which will still likely be added as a process chemical but in more moderate quantities than in the past. Sodium-containing solutions will likely be used only to wash the solvent (sodium carbonate solutions) and to periodically decontaminate facilities and equipment (sodium hydroxide solutions).

The bases for the composition ranges in Table 3 are given in the footnotes, and some are discussed more fully in the following text. These ranges assume that the intermediate-level liquid waste will be combined with the high-level liquid waste for vitrification. The quantities are given "per gram of fission product Cs," instead of the more traditional "per MTU," to reduce the number of instances where a range must be specified. This simplification is possible because the relative amounts of one fission product to another in LWR fuel are quite constant; they all increase with burnup in approximately equal proportion. The quantities per gram of Cs can be converted to quantities per MTU by multiplying by $0.0825 \mathrm{~g} \mathrm{Cs} / \mathrm{MWd}$ and by the burnup (MWd/MTU).

Gadolinium. The element having the largest range of likely quantity, and which therefore may be the one of most importance in defining the glass composition and/or the guantity of glass per MTU processed, is gadolinium. The uncertainty involving this element arises primarily from the uncertainty as to whether Gd would be used as a soluble poison in a future commercial fuel reprocessing plant; the odds on this appear to be about 50-50 for a large plant, with a lower probability of Gd use in smaller plants. If Gd is used, it appears to be likely that its concentration would be reduced as much as possible by first measuring the burnup of the fuel so that credit could be taken for its reduced reactivity. If this is not done, the Gd concentration 
must be based on the initial fuel enrichment (as was the plan at AGNS), and much higher Gd concentrations result.

The reduction in Gd content allowed by taking credit for burnup is currently not well defined. Ashline and Waltz (1978) report that Gd requirements can be reduced by a factor of up to 2 by doing so, but Heinicke and Thomas (1978) indicate that a much greater reduction is possible. These authors present data that indicate that a factor of 6 reduction is possible at a burnup of $30,000 \mathrm{MWd} / \mathrm{MTU}$.

The use of $\mathrm{Gd}_{2} \mathrm{O}_{3}$ as a burnable poison in fuel elements aimed at high burnups provides another potential source of gadolinium in HLW. The exact amount likely added is not well known at this time, but one estimate would result in the addition of $5 \mathrm{~kg} \mathrm{Gd/MTU}$ (Harris 1982).

Data illustrating some potential gadolinium content situations are given in Table 4. The first case is when Gd is not used as either a burnable poison in the fuel or as a soluble poison in the reprocessing plant. The second case illustrates the possible effect of having Gd present in the fuel as a burnable poison. The remaining seven cases are all based on no Gd in the fue1, but the use of Gd as a soluble poison in the reprocessing plant.

The first five of the cases involving $G d$ as a soluble poison are based on no credit being taken for the reduced fuel reactivity due to burnup. The Gd requirement increases markediy as the initial fuel enrichment increases. However, the concurrent increase in fission product content at higher exposures makes this increase less pronounced on a "per $\mathrm{g}$ Cs" basis.

The last two cases, in comparison with the corresponding enrichment case in the preceding set, show the marked reduction in $G d$ requirement that appears to be possible according to the data of Heinicke and Thomas (1978) by analyzing the fuel burnup before reprocessing and taking credit for the decreased reactivity in calculating the amount of Gd required.

As was mentioned earlier, it is thought that instrumentation to measure fuel burnup would be incorporated in a future reprocessing plant that does use Gd as a soluble poison, so that Gd usage will be kept to a minimum. The maximum value of $5 \mathrm{~g}$ added $\mathrm{Gd} / \mathrm{g}$ Cs listed in Table 3 is thought to provide a 
TABLE 4. Illustrations of Potential Gadolinium Contents of High-Level Waste

\begin{tabular}{|c|c|c|c|c|c|c|c|}
\hline \multirow[b]{2}{*}{$\begin{array}{l}\text { Use as Burnable } \\
\text { Poigon in Fuel? }\end{array}$} & \multirow[b]{2}{*}{$\begin{array}{l}\text { Use as Soluble } \\
\text { Poigon in Diss.? }\end{array}$} & \multirow{2}{*}{$\begin{array}{l}\text { If Used ag Soluble } \\
\text { Poison, is Credit } \\
\text { Iaken for Fuel Burnup? }\end{array}$} & \multirow[b]{2}{*}{$\begin{array}{l}\text { Initial }{ }^{235} \mathrm{U} \\
\text { In Fuel, }\end{array}$} & \multirow[b]{2}{*}{$\begin{array}{l}\text { Burnup, } \\
\text { MNd/MTU }\end{array}$} & \multicolumn{3}{|c|}{ Required Gd, $\mathrm{g}$} \\
\hline & & & & & Per liter (a) & Per $\operatorname{MTU}^{(\mathrm{b})}$ & Per g $C_{s}{ }^{(c)}$ \\
\hline No & No & -- & Any & Any & 0 & $\mathbf{0}$ & 0 \\
\hline Yes & No & $=-$ & $\sim 5$ & $\sim 50,000$ & $\rightarrow$ & $\sim 5 \times 10^{3}$ & $M .2$ \\
\hline No & Yes & No & 3.0 & Any & $4 . g^{(d)}$ & $13.4 \times 10^{3}$ & \\
\hline No & Yes & No & 3.5 & Any & 7.1 & $19.9 \times 10^{3}$ & $7.9^{(e)}$ \\
\hline No & Yes & No & 4.0 & Any & 10.0 & $28.0 \times 10^{3}$ & \\
\hline No & Yes & No & 4.5 & Any & 14.2 & $39.8 \times 10^{3}$ & \\
\hline No & Yes & No & 5.0 & Any & 20.8 & $58.3 \times 10^{3}$ & $13.9^{(f)}$ \\
\hline No & Yes & Yes & 3.5 & 20,000 & $1.9^{(g)}$ & 5. $3 \times 10^{3}$ & 3.2 \\
\hline No & Yes & Yes & 3.5 & 30,000 & 1.2 & $3.4 \times 10^{3}$ & 1.3 \\
\hline
\end{tabular}
(a) To give $k_{\text {eff }}=0.9$.
(b) Based on $1.5 \underline{M} \mathrm{U}$ in dissolver solution.
(c) Based on $0.0837 \mathrm{~g} C s$ produced per MHd.
(d) Data from Ashline and Waltz (1978).
(e) At 30,000 MNd/MTU.
(f) At 50,000 MNd/MTU.
(g) Data from Heinicke and Thomas (1978). 
likely upper level of added Gd, including that added to fuel as a burnable poison as well as that used as a soluble poison in the reprocessing plant.

Sodium. The presence of sodium in future comercial HLW will arise from two major sources: 1) sodium carbonate solutions used in solvent washing and 2) sodium hydroxide solutions used in equipment and facility cleaning. Alternative solvent wash solutions that do not add salts to the waste have been investigated in recent years. However, because such solutions appear to have no other advantage over sodium carbonate solutions and because the amount of $\mathrm{Na}$ added to the waste by sodium carbonate is less than that required for desirable glass properties, there appears to be little incentive for the use of such alternative solutions.

The quantity of sodium hydroxide used in equipment and facility cleaning will depend on the frequency of equipment failures and the maintenance concept of the plant. A contact maintained plant will require more facility cleaning before equipment repair and/or replacement than will a remotely maintained plant.

The quantity of $\mathrm{Na}$ that will be added to the waste in cleaning operations is much more difficult to estimate than the quantity that will be added as a result of normal flowsheet operations. The Na content of the waste estimated by AGNS in 1982 was $11 \mathrm{~kg} /$ MTU (Carr et al. 1982). According to AGNS personnel, this estimate is composed of $5 \mathrm{~kg} / \mathrm{MTU}$ for flowsheet usages and 6 $\mathrm{kg} /$ MTU for Na usage during cleaning operations. This value of $6 \mathrm{~kg} /$ MTU is the best estimate currently available, but it probably contains an appreciable uncertainty; an uncertainty of plus or minus a factor of two witl be assumed here, giving a range of 3 to $12 \mathrm{~kg} \mathrm{Na} /$ MTU from decontamination operations. Information obtained from G. L. Ritter of Exxon Nuclear Company indicates that the $\mathrm{Na}$ content of the waste from their proposed reprocessing plant was expected to be $3 \mathrm{~kg} / M T U$. It is not known whether this estimate included $\mathrm{Na}$ from cleaning operations, but it appears that it did not.

Iron, Chromium, and Nickel. The quantity of corrosion products estimated by AGNS personnel for the HLW planned to be produced at their plant was 0.3 $\mathrm{kg} / \mathrm{MTU}$. The corresponding estimate for the proposed Exxon Nuclear Plant was 
about 2-fold higher. Consideration of values ranging from 0.2 to $0.8 \mathrm{~kg} / \mathrm{MTU}$ appears to be warranted. Uniform corrosion of $304 \mathrm{~L}$ stainless steel was assumed in arriving at the quantities of $\mathrm{Fe}, \mathrm{Cr}$, and $\mathrm{Ni}$ listed in Table 3 .

Phosphorus. This element will be present in HLW in the forms of tributyl phosphate (TBP) and its degradation products, which are dibutyl phosphoric acid, monobutyl phosphoric acid, and phosphoric acid. The quantity of phosphorus in the waste from a future fuel reprocessing plant will depend on factors such as the phase separation efficiency of the solvent extraction equipment, the residence time in the solvent extraction equipment, whether aqueous raffinates are treated to remove TBP, whether intercycle concentrations are used, and the number of solvent extraction cycles employed.

Because of these many unknowns, it is difficult to accurately predict the phosphorus content of future HLW. However, the phosphorus content should not be very high, so this uncertainty may be relatively unimportant. The phosphorus content of HLW from the AGNS plant was estimated to be $1.6 \mathrm{~kg} \mathrm{P} / \mathrm{MTU}$ (Carr et aT. 1982). The estimated phosphorus content of the HLW from the proposed Exxon Nuclear Plant was markedly lower, $\sim 0.25 \mathrm{~kg} \mathrm{P} / \mathrm{MTU}$. These two values were used in arriving at the composition range listed in Table 3 .

Manganese. This element may be present in HLW as a result of using permanganate-containing decontamination solutions. The manganese content estimates of Table 2 are based on the assumption that $0.028 \mathrm{~g} \mathrm{Mn}$ is added to the HLW for each gram of sodium used in decontamination solutions.

Noble Metal Fission Products. Significant fractions of certain fission products do not dissolve when irradiated power reactor fuels are dissolved for reprocessing. The portions of the fission products present in dissolver residue thus need not be considered in developing glass formulations to incorporate the fission products. Even if this solid residue is added to the molten glass so that it will be disposed along with the remainder of the fission products, the residue will tend to remain in the form of metallic particles rather than being incorporated in the glass structure (Odoj and Aheimer 1984). 
The residues remaining from the dissolution of several LWR fuels irradiated to burnups of up to $28,000 \mathrm{MWd} / \mathrm{MTU}$ were characterized by workers at Savannah River Laboratory. They determined the approximate composition of the residue from $28,000 \mathrm{MWd} / \mathrm{MTN}$ fuel and also determined that $\sim 30 \%$ of the total Ru was present in the residue. The fractions of other fission products present in the residue can be calculated from this information, plus the quantities present in the fuel. Results of such calculations are compared with those of Odoj and Aheimer (1984), which included British and German results, in Table 5. These results are in good agreement and show that only $\mathrm{Ag}, \mathrm{Ru}$ and $\mathrm{Rh}$ appear in the residue in amounts that represent a substantial fraction of the total present in the fuel. The Savannah River workers also found that the quantity of residue increased linearly with burnup. It thus appears likely that the fractions of noble metal fission products in the residue are independent of burnup.

The ultimate disposition of these highly radioactive dissolver residues is currently uncertain. They will likely be separated by centrifugation or filtration before the dissolved fuel is processed by solvent extraction. However, it has not been decided whether the separated solids should be treated as a separate waste stream or should be added to the HLW. Based on past experience with similar process options, it is likely that different choices will be made by different plant operators.

Odoj and Aheimer (1984) investigated the vitrification of dissolver residues and concluded that the process did not seem suitable because inhomogeneous products were obtained. Others feel that such inhomogeneity can be tolerated. However, even if such product inhomogeneity is acceptable the residues may cause operating problems in some types of vitrification processes. For example, wi th continuously fed, joule-heated melters, there is concern that such solids could accumulate and eventually cause electrical shorting across the electrodes.

WASTE FROM REPROCESSING OF LMR FUEL

Liquid metal reactors (LMRs) are being developed extensively abroad and to a lesser extent in the United States. The general concept of the fuel cycle for such reactors has been centered on mixed oxide $\left[(U, P u) O_{2}\right]$ fuels and 
TABLE 5. Fractions of Fission Products in Dissolver Residue with LWR Fuel

\begin{tabular}{|c|c|c|c|}
\hline Element & $\begin{array}{l}\text { Calculafed } \\
\text { here }\end{array}$ & $\begin{array}{l}\text { in Residue/Gram in } \\
\text { Reported by Odoj } \\
\text { and Aheimer (1984) }\end{array}$ & Average $^{(b)}$ \\
\hline $\mathrm{Ag}$ & 0.6 & 1.0 & 0.8 \\
\hline $\mathrm{Ru}$ & 0.30 & 0.37 & 0.33 \\
\hline Rh & 0.23 & 0.37 & 0.30 \\
\hline Pd & 0.09 & 0.10 & 0.10 \\
\hline$M 0$ & 0.09 & 0.10 & 0.10 \\
\hline TC & 0.06 & 0.08 & 0.07 \\
\hline $\mathrm{Zr}$ & 0.01 & 0.14 & 0.07 \\
\hline
\end{tabular}

(a) From Savannah River Laboratory information.

(b) Values used in determining data of Table 3.

reprocessing by the PUREX process. Such a fuel cycle results in high level wastes that are very similar to those resulting from reprocessing of LWR fuels. However, the U.S. has recently embarked on consideration and examination of an alternative approach, which involves a different. type of fuel and a different reprocessing technique that would result in markedly different high-level wastes. We will first address the wastes resulting from the conventional LMR fuel cycle and then discuss the alternative LMR fuel cycle currently under investigation in the U.S.

Wastes from Conventional LMR Fuel Reprocessing

The conventional LMR fuel cycle approach involves stainless steel clad, mixed oxide $\left[(\mathrm{U}, \mathrm{Pu})_{2}\right]$ fuels that are irradiated in 1 iquid sodium-cooled reactors. As with LWR fuel, LMR fuel is prepared for reprocessing by shearing or chopping it into short lengths to expose the core so that it can be dissolved out of the cladding tubes with nitric acid, and plutonium and uranium recovery and purification are then accomplished by the PIREXX 
process. As well as being the preferred approach abroad, this fuel cycle is also, along with the alternative concept to be discussed later, one of the options being addressed in on-going evaluations of new LMR concepts in the U.S.

A typical LMR may contain three different kinds of fuel. Driver fuel is the $(U, \mathrm{Pu})_{2}$ fuel in which the bulk of the fissioning process occurs. Axial blanket fuel is $\mathrm{UO}_{2}$ that is positioned at either end of the driver fuel; this is generally contained within the same fuel rods as the driver fuel. Radial blanket fuel is $\mathrm{UO}_{2}$ that is contained in separate elements around the elements containing driver and axial blanket fuels. These three types of fuel typically undergo different burnups; thus, the composition of the high-level waste resulting from reprocessing depends on whether they are reprocessed together. If they are reprocessed together in the same facility, either at the same time or in separate campaigns from which the wastes are blended before they are vitrified, the high-level waste composition will be a weighted average of the compositions resulting from separate reprocessing.

Croff and Alexander (1980) give data on the relative quantities of fission product and actinide elements present in the three types of fuel in a hypothetical LMR. Some of these data are given in Table 6, presented as the (weight) ratio of these components to fission product cesium. These ratios should be quite comparable to those in LMRs of different designs. However, the relative amounts of the different fuel types can vary markedly from one LMR design to another. Because the vast majority of fission products will be formed in the driver (core) fuel, this uncertainty does not substantially affect our current knowledge of the fission product content of such future wastes. However, this uncertainty regarding the relative amounts of the different types of fuel does affect our current ability to accurately predict the quantities of some other HLW components, which are more a function of heavy metal throughput rather than of fuel burnup.

Table 7 presents probable composition ranges for HLW resulting from future conventional reprocessing of LMR fuels. The fission product and actinide values are weighted averages of the values given in Table 6 for the three types of LMR fuels addressed by Croff and Alexander (1980). The assumption is being made for this table therefore, that the different types of 
TABLE 6. Fission Product and Actinide Contents, Relative to Cesium, of LMR Fuels

\begin{tabular}{|c|c|c|c|}
\hline Element & Core ${ }^{(a)}$ & $\begin{array}{c}\text { Axial } \\
\text { Blanket }\end{array}$ & $\begin{array}{l}\text { Radial } \\
\text { Blanket }(c)\end{array}$ \\
\hline $\mathrm{Se}$ & 0.0105 & 0.0132 & 0.0129 \\
\hline$R b$ & 0.0540 & 0.0676 & 0.0666 \\
\hline Sr & 0.1224 & 0.1555 & 0.1529 \\
\hline$y$ & 0.0639 & 0.0827 & 0.0814 \\
\hline $\mathrm{Zr}$ & 0.6630 & 0.7514 & 0.7465 \\
\hline$M$ & 0.8014 & 0.8389 & 0.8525 \\
\hline TC & 0.2071 & 0.2217 & 0.2200 \\
\hline $\mathrm{Ru}$ & 0.8081 & 0.7756 & 0.7813 \\
\hline $\mathrm{Rh}$ & 0.2316 & 0.2356 & 0.2348 \\
\hline $\mathrm{Pd}$ & 0.6305 & 0.4822 & 0.4947 \\
\hline $\mathrm{Ag}$ & 0.0680 & 0.0523 & 0.0530 \\
\hline$c d$ & 0.0740 & 0.0666 & 0.0659 \\
\hline Sn & 0.0778 & 0.0832 & 0.0810 \\
\hline $\mathrm{Te}$ & 0.1738 & 0.1817 & 0.1808 \\
\hline Cs & 1.000 & 1.000 & 1.000 \\
\hline $\mathrm{Ba}$ & 0.3645 & 0.3471 & 0.3519 \\
\hline La & 0.3036 & 0.3087 & 0.3085 \\
\hline $\mathrm{Ce}$ & 0.5792 & 0.6011 & 0.5990 \\
\hline $\operatorname{Pr}$ & 0.2818 & 0.2887 & 0.2920 \\
\hline Nd & 0.8838 & 0.9322 & 0.9302 \\
\hline Pm & 0.0484 & 0.0704 & 0.0655 \\
\hline Sm & 0.2596 & 0.2383 & 0.2432 \\
\hline Eu & 0.0339 & 0.0324 & 0.0323 \\
\hline Gd & 0.0290 & 0.0201 & 0.0212 \\
\hline U & 65.08 & 1538 & 1202 \\
\hline$N p$ & 0.0410 & 0.1282 & 0.1296 \\
\hline Pu & 15.46 & 51.48 & 45.66 \\
\hline$A m+C m$ & 0.3403 & 0.00431 & 0.00502 \\
\hline
\end{tabular}

(a) $9.79 \mathrm{MTHM}(18.5 \% \mathrm{Pu})$ irradiated for 3 years to give 101,300 MWd/MTHM then cooled 1 year. $0.1094 \mathrm{~g} \mathrm{Cs/MWd.}$

(b) 6.05 MTHM irradiated for 3 years to give 5660 MWd/MTHM, then cooled 1 year. $0.1105 \mathrm{~g} \mathrm{Cs} / \mathrm{MWd}$.

(c) 7.98 MTHM irradiated for 6 years to give 7220 MWd/MTHM, then cooled 1 year. 0.1102 a $\mathrm{Cs} / \mathrm{MWd}$. 
TABLE 7. Composition Ranges Likely in High-Level Liquid Wastes from Future Conventional Reprocessing of LMR Fuel

\begin{tabular}{|c|c|c|}
\hline Element & Source & $\mathrm{g}$ Element/g $\mathrm{Cs}_{\mathrm{s}}(\mathrm{h})$ \\
\hline $\begin{array}{l}\mathrm{Se} \\
\mathrm{Rb} \\
\mathrm{Sr} \\
\mathrm{Y} \\
\mathrm{Zr} \\
\mathrm{Mo} \\
\mathrm{TC} \\
\mathrm{Ru} \\
\mathrm{Rh} \\
\mathrm{Pd} \\
\mathrm{Ag} \\
\mathrm{Cd} \\
\mathrm{Sn} \\
\mathrm{Te} \\
\mathrm{CS} \\
\mathrm{Ba} \\
\mathrm{La} \\
\mathrm{Ce} \\
\mathrm{Pr} \\
\text { Nd } \\
\mathrm{Pm} \\
\text { Sm } \\
\text { Eu } \\
\text { Gd } \\
\text { Added Gd } \\
\text { Total La-Gd }\end{array}$ & $\begin{array}{l}\text { (a) } \\
\text { (a) } \\
\text { (a) } \\
\text { a) } \\
\text { a) } \\
\text { (a) } \\
\text { (a) } \\
(a) \\
(a) \\
(a) \\
(a) \\
\text { (a) } \\
\text { (a) } \\
\text { (a) } \\
\text { (a) } \\
\text { (a) } \\
\text { (a) } \\
\text { (a) } \\
\text { (a) } \\
\text { (a) } \\
\text { (a) } \\
\text { (a) } \\
\text { (b) } \\
\text { (a+b) }\end{array}$ & $\begin{array}{l}0.0107 \\
0.0548 \\
0.124 \\
0.065 \\
0.668 \\
0.322^{(i)} \\
0.0416^{(i)} \\
0.0806^{(i)} \\
0.0232^{(i)} \\
0.498^{(i)} \\
0.0470^{(i)} \\
0.0736 \\
0.0781 \\
0.174 \\
1.000 \\
0.364 \\
0.304 \\
0.581 \\
0.282 \\
0.887 \\
0.0496 \\
0.258 \\
0.0338 \\
0.0285 \\
0-0.3^{(j)} \\
2.4-2.7\end{array}$ \\
\hline $\begin{array}{l}\mathrm{U} \\
\mathrm{Np} \\
\mathrm{Pu} \\
\mathrm{Am}+\mathrm{Cm}\end{array}$ & $\begin{array}{l}\text { (c) } \\
\text { (d) } \\
\text { (c) } \\
\text { (d) }\end{array}$ & $\begin{array}{l}0.3-1.5^{(k)} \\
0.0463 \\
0.035-0.18^{(k)} \\
0.320\end{array}$ \\
\hline $\begin{array}{l}\mathrm{Na} \\
\mathrm{Mn} \\
\mathrm{Fe} \\
\mathrm{Cr} \\
\mathrm{Ni}\end{array}$ & $\begin{array}{l}(b+e+f) \\
(e) \\
(g) \\
(g) \\
(g)\end{array}$ & $\begin{array}{l}1.0-3.3^{(1)} \\
0.014-0.058^{(m)} \\
0.078-0.67(n) \\
0.022-0.19(n) \\
0.011-0.096^{(n)}\end{array}$ \\
\hline $\begin{array}{l}P \\
F\end{array}$ & $\begin{array}{l}\text { (b) } \\
\text { (b) }\end{array}$ & $\begin{array}{l}0.052-0,2 b^{(0)} \\
0-0.003(p)\end{array}$ \\
\hline A] & (b) & $0-0.014(q)$ \\
\hline
\end{tabular}




\section{Footnotes to Tabie 7}

(a) Fission product.

(b) Flowsheet chemical.

(c) Waste 105s.

(d) Unrecovered actinide.

(e) Decontamination chemical.

(f) Coolant that adhered to fuel.

(g) Corrosion product.

(h) To convert to g/MTHM, multiply by (MWd/MTU burnup) and by $0.11 \mathrm{~g}$ Cs/MWd. These fission product values are weighted averages of the data in Table 6 .

(i) Based on the fractions undissolved given in the discussion (Table 9). These are 0.3 for $\mathrm{Ag}, 0.9$ for $\mathrm{Ru}$ and $\mathrm{Rh}, 0.2$ for Pd, 0.6 for Mo, and 0.8 for TC.

(j) High value is based on the use of Gd as a soluble poison, with Gd concentration based on Pu concentration (see text), with $350 \mathrm{~g} \mathrm{Pu}+$ $\mathrm{U} / \mathrm{L}$ in feed solution, and blended core and blanket fuels (Table 6).

(k) Range is based on 0.2 to $1.0 \%$ waste loss.

(1) Low value is based on $0 \mathrm{~kg} \mathrm{Na} /$ MTHM residual on fuel, $3 \mathrm{~kg} \mathrm{Na} /$ MTHM from solvent washing, and $3 \mathrm{~kg} \mathrm{Na} / \mathrm{MTH}$ il from decontamination solutions. High value is based on 2,5 , and $12 \mathrm{~kg} \mathrm{Na} / \mathrm{MTHM}$, respectively, from these sources.

(m) Values based on $0.028 \mathrm{~g} \mathrm{Mn} / \mathrm{g}$ Na used in decontamination solutions.

(n) Values based on LMR fuel having $500 \mathrm{~kg}$ cladding steel/MTHM (see Table 8 ), and equipment corrosion values as used in LWR fuel case (Table $3)$. Low value is based on dissolution of $0.1 \%$ of cladding 10.5 $\mathrm{kg} / \mathrm{MTHM}$ ) and $0.15 \mathrm{~kg} / \mathrm{MTHM}$ from equipment corrosion. High value is based on dissolution of $1 \% \mathrm{cladding}(5.0 \mathrm{~kg} / \mathrm{MTHM})$ and $0.60 \mathrm{~kg} / \mathrm{MTHM}$ from equipment corrosion. Uni form dissolution of $70 \% \mathrm{Fe}, 20 \% \mathrm{Cr}$, and $10 \% \mathrm{Ni}$ steel is assumed.

(o) Based on 0.3 to $1.2 \mathrm{~kg} \mathrm{P} / \mathrm{MTHM}$.

(p) High value based on $1 \%$ of $\mathrm{PuO}_{2}$ remaining after $\mathrm{HNO}_{3}$ dissolution and being dissolved in $\mathrm{HNO}_{3}+0.1 \mathrm{M}^{2} \mathrm{HF}$ to $100 \mathrm{~g} \mathrm{Pu} / \mathrm{L}$.

(q) Based on 3 mole Al per mole $F$. 
fuel will be reprocessed together in the same facility, either at the same time or in separate campaigns with blending of the wastes before they are vitrified. The footnotes of this table, and additional discussion in the text, provide more detail regarding the quantities of the other components.

Uranium. Among the reprocessing options with LMR fuels is the fate of the uranium. The depleted uranium commonly used in LMR fuels has little intrinsic value, so its fate will likely be decided by the costs of storing or disposing of the excess. The excess of uranium arises from the perception that it is more cost effective to fabricate the axial blanket pellets, and the entire radial blanket assemblies, using depleted uranium from other sources rather than using depleted uranium recovered from the irradiated elements. It is not known if the cost of storing or disposing of the resultant excess uranium was factored into this perceived cost effectiveness.

If excess uranium does indeed result in the LMR fuel cycle, it can be disposed of by: 1) combining it with the high-level waste for immobilization and disposal, 2) performing a partial purification and converting it to oxide for repository disposal as a transuranic (TRU) waste, or 3) purifying it extensively before it is converted to oxide and disposed of as a low-level waste. The first option, adding the excess uranium to the HLW, would have a markedly adverse effect on the preparation of glasses having high fission product loadings; however, it might be a cost effective option if fission product loadings are 1 imited by repository heat load constraints. The other two options are essentially equivalent insofar as high-level waste composition is concerned. The current study assumes that either option 2 or 3 will be implemented with a small loss of uranium (and plutonium) to the HLW.

Gadolinium. As in the LWR case discussed earlier, there is uncertainty whether Gd would be used as a soluble nuclear poison during reprocessing of LMR fuels. If such reprocessing is done at a single reactor, as is the concept currently being examined in this country, the likelihood of Gd being used is decreased because of the smallness of the equipment that could be used to handle the required processing rate. 
The concentration of Gd required to maintain subcriticality in a typical LMR fuel solution has been estimated by R. T. Primm, III of Oak Ridge National Laboratory as

$$
[G d]=\frac{\left[P_{u}\right]^{2}}{1000},
$$

with the concentrations expressed as $\mathrm{g} / \mathrm{L}$. At typical concentrations of $\mathrm{Pu}$ in LMR feed solutions, this results in a lower Gd-to-Cs ratio in the HLW from LMR fuel reprocessing (Table 7) than from LWR fuel reprocessing (Table 3). The use of Gd as soluble neutron poison in LMR fuel reprocessing would have relatively little impact on the minimum quantity of HLW glass.

Sodium. The HLW from LMR fuel reprocessing may contain sodium from a different source than in LWR fuel reprocessing. This added source is the solution generated when metallic sodium coolant that adheres to the fuel elements is reacted prior to the reprocessing operations. E. A. Aitken of General Electric Company indicates that this would amount to $\sim 2 \mathrm{~kg} \mathrm{Na} / \mathrm{MTHM}$.

The quantities of sodium in solvent washing wastes and in equipment and facility decontamination solutions should be approximately the same in a LMR fuel reprocessing plant as in a LWR fuel reprocessing plant.

All of these sodium-containing waste streams could be immobilized in a separate waste treatment system. However, because these quantities of sodium are low relative to the amount generally required in glass making, their treatment and disposal along with the HLW appears to be much more cost effective. That is the approach assumed here, and in nearly all recent reprocessing plant design planning.

Iron, Chromium, and Nickel. These elements are present in LMR fuel HLW not only as a result of equipment corrosion, but also because a fraction of the stainless steel cladding dissolves in nitric acid. The extent of cladding dissolution is greater than would be otherwise expected because of sensitization that occurs during reactor exposure.

According to D. 0. Campbell of Oak Ridge National Laboratory, the extent of irradiated cladding dissolution has varied widely in laboratory tests. In 
some cases $1 \%$ of the cladding dissolved but in other cases less than $0.1 \%$ dissolved. Thus, there is considerable uncertainty regarding the concentrations of $\mathrm{Fe}, \mathrm{Cr}$, and $\mathrm{Ni}$ to be expected in $\mathrm{HLW}$ as a result of cladding dissolution.

Data on the total quantities of stainless steel, and on that present in the cladding, in some typical LMR fuel elements are given in Table 8 . If $1 \%$ of the cladding did dissolve along with the core, the stainless steel content of the HLW would range from 2 to $8 \mathrm{~kg} /$ MTHM with these three LMR fuel elements.

Phosphorus. The phosphorus content, per unit of fuel processed, of the solvent washing waste streams from LMR fuel reprocessing should be approximately the same as in the LWR fuel reprocessing case.

Manganese. As in the LWR case, the manganese concentration of LMR fue 1 $\mathrm{HLW}$ is assumed to be $0.028 \mathrm{~g}$ Mn per gram of sodium used in decontamination solutions.

Noble Metal Fission Products. Oata on the fractions of the noble metal fission products that remain in the dissolver residue when LMR mixed-oxide fuel is dissolved in nitric acid are summarized in Table 9. Comparison of these data with those for LWR fuel (Table 4) show that, except for silver,

TABLE 8. Stainless Steel Contents of LMR Fuel Elements

\begin{tabular}{|c|c|c|c|}
\hline Fuel As sembly & $\begin{array}{l}\text { Total Stainless } \\
\text { Steel, } \mathrm{Kg} / \mathrm{MTHM}\end{array}$ & $\begin{array}{l}\text { Stainless Steel } \\
\text { in Cladding, } 8 \\
\end{array}$ & $\begin{array}{c}\text { Cladding Stainless } \\
\text { Steel, } \mathrm{Kg} / \text { MTHM }\end{array}$ \\
\hline FFTF $^{\text {(a) }}$ & 3790 & 21 & 800 \\
\hline CRBR Core (b) & 2250 & 24 & 540 \\
\hline CRBR Blanket (b) & 1220 & 17 & 210 \\
\hline
\end{tabular}

(a) Data from Croff, Liberman, and Morrison (1982).

(b) Data from Croff and Bjerke (1982). 
TABLE 9. Fractions of Fission Products in Dissolver Residue with LMR Fuel

\begin{tabular}{|c|c|c|c|}
\hline \multirow[b]{2}{*}{ Element } & \multicolumn{3}{|c|}{ Gram in Residue/Gram in Fuel } \\
\hline & $\begin{array}{l}\text { CampbelT } \\
\text { et a T. (1981) }\end{array}$ & $\begin{array}{l}\text { CampbeT } \\
\text { et al. (1982) }\end{array}$ & $\begin{array}{l}\text { Selected } \\
\text { value }(a)\end{array}$ \\
\hline $\mathrm{Ag}$ & 0.02 & $<0.5$ & 0.3 \\
\hline Ru & 0.75 & $>0.9$ & 0.9 \\
\hline Rh & 0.78 & $>0.9$ & 0.9 \\
\hline $\mathrm{Pd}$ & 0.06 & $\sim 0.5$ & 0.2 \\
\hline Mo & 0.43 & $\sim 0.8$ & 0.6 \\
\hline Tc & 0.58 & $>0.9$ & 0.8 \\
\hline
\end{tabular}

(a) Values used in determining data of Table 7.

substantially larger fractions remain undissolved in the LMR cases. This increases the magnitude of the potential difficulty in handling such solids, as was discussed in the LWR case.

Fluoride and Aluminum. These are two components that may be present in the HLW from processing LMR fuels that are not likely to be present in the HLW from LWR fuels. This is because the solid residues remaining after dissolution of mixed oxide LMR fuels in nitric acid contain a small fraction of the Pu that resists dissolution by $\mathrm{HNO}_{3}$ alone. Because of the high concentration of Pu in such fuels this small fraction may still be worth recovering. The nomal procedure to effect this recovery is to leach the residue with an $\mathrm{HNO}_{3} / \mathrm{HF}$ mixture, which effectively dissolves the residual $\mathrm{PuO}_{2}$. Such an operation would likely be performed in a small secondary dissolver.

Because of the corrosiveness of fluoride to stainless steel, aluminum would likely be added to the solutions resulting from a $\mathrm{HNO}_{3} / \mathrm{HF}$ leach of the dissolver residue. Aluminum ions form strong complexes with fluoride ions so that the free fluoride concentration and the corrosion rate are markediy reduced.

The fraction of $\mathrm{Pu}$ that does not dissolve in nitric acid depends on the $\mathrm{PuO}_{2}$ content of the fuel, which is generally kept below about $35 \%$ to give good 
dissolution behavior, and on the fuel fabrication and/or irradiation conditions. In some typical instances this fraction is less than 0.001 (Campbe11, Mailen, and McTaggart, 1985). Whether such a low fraction should be recovered, thus introducing fluoride and aluminum to the HLW, or should be disposed of as waste is another instance where different future reprocessors may make different decisions. The high values shown for fluoride and aluminum in Table 7 represent quantities likely to be present in HLW if the decision is made to treat the residue and if the $\mathrm{HNO}_{3}$-insoluble $\mathrm{Pu}$ fraction is 0.01 .

\section{Waste from Pyrochemical LMR Fuel Reprocessing}

The so-called Integral Fast Reactor (IFR) fuel cycle concept currently under development at Argonne National Laboratory (ANL) employs metallic alloy fuel elements and pyrochemical fuel reprocessing techniques. This should not be taken to mean that such fuel elements and reprocessing techniques are necessary for an integral fast reactor fuel cycle. Such a cycle can also involve the traditional oxide fuel elements and PUREX processing, as was discussed in the preceding section.

In the ANL IFR reprocessing concept, as described by Miller et al. (1985), stainless steel clad, metal alloy (U-Pu-Zr) fuel rods are sectioned to expose the alloy, which is then dissolved in molten cadmium. This molten cadmium phase is then made the anode of an electrorefining cell, which contains a molten chloride salt electrolyte. With the passage of an electric current under a properly applied voltage, $U$ and $P u$ are oxidized from the cadmium and simultaneously reduced from the electrolyte and deposited as metals onto an iron cathode surface. Alkali metal, alkaline earth, rare earth, and iodine fission products favor the electrolyte; the remainder of the fission products and the insoluble cladding stay in the anode. Two separate purification systems are used, one for core elements and one for blanket elements. Blanket element processing requires an additional step, halide slagging, to recover the $\mathrm{Pu}$ from the $U$ so that it can be recycled to the core. The metallic deposits, which are dendritic in nature, are melted to consolidate them and to separate off the occluded salt. They are then remelted and cast into fuel rods. 
There are three major waste streams from this process: 1) chloride salts that had made up the molten salt electrolyte, 2) cadmi um ingots that had formed the molten cadmium anode, and 3) a ceramic waste containing Be0 crucibles and aluminum silicate fume traps. The salts contain the bulk of the alkali metal, alkaline earth, rare earth, and iodine fission products and the cadmium contains the bulk of the other nonvolatile fission products and the cladding material. Both the salt and the metal streams will also be contaminated with roughly $1000 \mathrm{ppm}$ of actinides, according to $T$. F. Johnson of ANL.

Neither the salt nor the metal waste streams appears to be very amenable for conversion to a glass waste form. Several approaches are under considerations for treating these wastes (Johnson et a1. 1985). Some of these approaches involve disposal of the wastes in the as-generated form, while others involve steps to provide materials suitable for vitrification feeds. Anong such steps are: 1) oxidative slagging to transfer actinides from the metal phase into a low-melting mixture of hydroxides, borates, and carbonates and 2) pyrohydrolysis or electrolysis to remove the chlorine present in the electrolyte salts. T. R. Johnson of ANL estimates that the approximate composition of pyrohydrolyzed salt would be as given in Table 10 . The relative proportions of the individual fission products would be approximately the same as those given in Table 6 for oxide fuel.

It could also be desirable to incorporate the ceramic wastes into a glass waste form along with the pyrohydrolyzed salt. The quantities involved, according to Johnson of $\mathrm{ANL}$, are $\sim 0.5 \mathrm{~g}$ BeO and $\sim 0.3 \mathrm{~g}$ aluminum silicate per gram of oxide from the pyrohydrolyzed salt (Table 10). 
TABLE 10. Approximate Composition of Pyrohydrolyzed Salts from Pyrochemical Reprocessing

\begin{tabular}{lc} 
Component & Approximate Amount, $\%$ \\
\cline { 3 - 3 } $\mathrm{Li}_{2} \mathrm{O}$ & 10 \\
$\mathrm{Na}_{2} \mathrm{O}$ & 6 \\
$\mathrm{CaO}$ & 21 \\
$\mathrm{Ba} 0$ & 33 \\
Oxides of alkali metal & \\
$\quad$ fission products & 7 \\
Oxides of alkaline earth & \\
$\quad$ fission products & 4 \\
Oxides of rare earth & \\
$\quad$ fission products & 19
\end{tabular}




\section{REFERENCES}

Ashline, R. C., and W. R. Waltz. 1978. "Use of Gadolinium Nitrate for Criticality Control During Fuel Dissolution." Trans. Am. Nuc1. Soc. 30:604-605.

Campbe11, D. 0., J. H. Goode, J. W. Roddy, and P. C. Arwood. 1982. "Solution Stability and Solids Characterization." In Consolidated Fuel Reprocessing Progran Progress Report for Period January 1 to March 31, 1982. 0RNL/TM8311, Oak Ridge National Laboratory, Oak Ridge, Tennessee.

Campbell, D. 0., J. H. Goode, W. L. Pattison, P. C. Arwood, and W. M. Caldwe11. 1981. "Solution Stability and Solids Characterization." In Consolidated Fuel Reprocessing Program Progress Report for Period April 1 to June 30, 1981. ORNL/TM-7914, Oak Ridge National Laboratory, Oak Ridge, Tennessee.

Campbe11, D. 0. , J. C. Mailen, and D. R. McTaggert. 1985. "Fue1 Characteristics and Dissolution Behavior." In Consolidated Fuel Reprocessing Program Progress Report for Period April 1 to June 30, 1985. ORNL/TM-9734, Oak Ridge National Laboratory, Oak Ridge, Tennessee.

Carr, W. H., R. C. Ashline, J. H. Gray, and R. C. Mitchell. 1982. Estimation of Nuclear Waste Types, Characteristics, and quantities from the Barnwell Nuc Tear Fue plant. ONWI/3092/TOP-01, Rev. 1, AlTied-General Nuc lear Services, BarnweIT, South Carolina.

Chick, L. A., J. L. Swanson, and D. S. Goldman. 1984. "Nuclear Waste Glass Composition Limitations." In Fuel Reprocessing and Waste Management, American Nuclear Society, La Grande Park, IITinois.

Croff, A. G., and C. W. Alexander. 1980. Decay Characteristics of OnceThrough LWR and LMFBR Spent Fuels, High-Level Wastes, and Fuel-As sembTy Structural Material Wastes. ORNL/TM-7431, Oak Ridge National Laboratory, Oak Ridge, Tennessee.

Croff, A. G., M. S. Liberman, and G. H. Morrison. 1982. Graphical and Tabular Summaries of Decay Characteristics for Once-through PWR, LMFBR, and FFTF Fuel Cycle Materials. ORNL/TM-8061, Oak Ridge National Laboratory, Oak Ridge, Tenneessee.

Harris, R. P. 1982. Use of Gadolinium in PWR Extended Burnup Fuel Cycles. CEND-397, Combustion Engineering, Inc., Windsor, Connecticut.

Heinicke, W., and W. Thomas. 1978. "Criticality Control for U/Pu Systems." Trans. Am. Nucl. Soc. 30:605-606.

Johnson, T. R., W. E. Miller, and R. K. Steunenberg. 1985. "Proposed Methods for Treating High-Level Pyrochemical Process Wastes." Trans. Am. Nucl. Soc. 50:207. 
Mailen, J. C., and 0. K. Tallent. 1984. "Solvent Cleanup and Degradation: A Survey and Recent ORNL Results." In Fuel Reprocessing and Waste Management, Anerican Nuclear Society, La Grange Park. IITinois.

McKee, R. H. , H. K. Elder, R. F. McCallum, D. J. Silviera, J. L. Swanson, and L. E. Wiles. 1983. A Systems Study of the Feasibility of High-Level Nuclear Waste Fractionation for Themal Stress Control in A Geologic Repository, PNL-4530, Pacific Northwest Laboratory, Richland, Washington.

Miller, W. E., T. R. Johnson, and Z. Tomczuk. 1985. "Choice of Pyroprocess for Integrai Fast Reactor Fue1." Trans. An. Nucl. Soc. 50:205.

Odoj, R., and D. Aheimer. 1984. "Vitrification of Highly Radioactive Dissolver STudges." In Fuel Reprocessing and Waste Management, American Nuclear Society, La Grange Park, MTinois. 
No. of

Copies

OFFSITE

\section{DOE Technical Information Center}

R. D. Walton, dr., DP-123

DOE Office of Defense Waste and Byproducts Management GTN

Washington, D.C. 20545

3. A. Coleman, NE-25

DOE Office of Teminal Waste GTN

Washington, D.C. 20545

T. W. McIntosh, NE-25

DOE Office of Terminal Waste Disposal and Remedial Action GTN

Washington, D.C. 20545

J. B. Zorn, NE-25

DOE Office of Terminal Waste Disposal and Remedial Action GTN

Washington, D.C. 20545

W. H. Hannum

DOE West Valley Dperations Office

P.0. Box 191

West Valley, NY 14171

J. D. Hamric/J. B. Whitsett

DOE Idaho Operations Office

550 Second Street

Idaho Falls, ID 83401
No. of

Copies

R. Stein, RW-23

Engineering and Licensing Division

DOE Dffice of Civilian

Radioactive Waste Management

Forrestal Building

Washington, D.C. 20585

L. Barrett, RW-33

Transportation and Waste

Systems Division

OOE Office of Civilian

Radioactive Waste Management

Forrestal Building

Washington, D.C. 20585

L. Lanni

DOE San Francisco Operations

1333 Broadway

San Francisco, CA 94612

G. K. Derte 1

DOE Savannah River Operations Office

P.0. Box A

Aiken, SC 29801

C. S. Abrams/J. H. Kittel

Argonne National Laboratory

9700 South Cass Avenue

Argonne, IL 60439

M. J. Steindler/L. E. Trevorrow Argonne National Laboratory 9700 South Cass Avenue

Argonne, IL 60439

B. Rawles

Battelle Memorial Institute Project Management Division $505 \mathrm{King}$ Avenue

Columbus, $\mathrm{OH} 43201$ 
Ho. of

Copies

F. Holzer

Lawrence Livermore National Laboratory

University of California

P.0. Box 808

Livermore, CA 94550

0. T. Oakley, MS 671

Los Alamos Scientific Laboratory

P.0. Box 1663

Los Alamos, NM 87544

D. 0. Campbe11

Oak Ridge National Laboratory

P. 0. Box $X$

Oak Ridge, TN 37830

T. H. Row/J. 0. Blomeke

Oak Ridge National Laboratory

P.0. Box $X$

Oak Ridge, TN 37830

H. F. Walter, NE-25

DOE Office of Terminal Waste Disposal and Remedial Action GTN

Washington, D.C. 20545

Technical Library

Sandia Laboratories

P.0. Box 5800

Albuquerque, NM 87185

B. R. Wheeler

Westinghouse Idaho Nuclear

Co., Inc.

P.0. Box 4000

Idaho Falls, I0 83401

M. D. Boersma

E. 1. du Pont de Nemours Company

Savannah River Laboratory

Aiken, SC 29801
No, of

Copies

J. R. Glasscock

E. I. du Pont de Nemours Company

Savannah River Laboratory

Aiken, SC 29801

J. R. Knight

E. I. du Pont de Nemours Company

Savannah River Laboratory

Aiken, SC 29801

M. J. Plodinec

E. I. du Pont de Nemours Company

Savannah River Laboratory

Aiken, SC 29801

C. T. Randall

E. I. du Pont de Nemours Company

Savannah River Laboratory

Aiken, SC 29801

E. A. Jennrich

EG\&G Idaho

P.D. Box 1625

Idaho Falls, IO 83415

K. V. Gilbert/P. G. Hagen

Rockwell International

Rocky Flats Plant

P.0. Box 464

Golden, CO 80401

C. C. Chapman

West Valley Nuclear Services

Company

P.0. Box 191

West Valley, NY 14171

J. C. Cwynar

West Valley Nuclear Services Company

P.D. Box 191

West Valley, NY 14171 
No. of

Copies

L. R. Eisenstatt

West Valley Nuclear Services

Company

P.0. Box 191

West Valley, NY 14171

J. L. Knabenschuh

West Valley Nuclear Services Company

P.0. Box 191

West Valley, NY 14171

J. E. Krauss

West Valley Nuclear Services

Company

P.0. Box 191

West Valley, NY 14171

J. M. Pope

West Valley Nuclear Services

Company

P.0. Box 191

West Valley, NY 14171

ONSITE

7 DOE Richland Operations Office

E. A. Bracken

G. J. Bracken

J. J. Broderick

R. D. Izatt

M. J. Plahuta

M. H. Shupe

J. D. White

12 Rockwell Hanford Operations
No. of

Copies

A. J. Di Loberto

L. M. Sasaki

D. K. Steiner

D. M. Talberg

File Copy

2 Westinghouse Hanford Company

R. E. Lerch

J. D. Watrous

47 Pacific Northwest Laboratory

S. 0. Bates

H. T. Blair

W. F. Bonner

L. A. Bray

R. A. Brouns

H. C. Burkholder

S. T. Freim

D. E. Knowlton

D. E. Larson

J. M. Latkovich

S. C. Marschman

J. L. McElroy

J. E. Mende1/M. D. Merz/

G. B. Mellinger

J. E. Minor/C. Allen

L. G. Morgan

W. L. Partain

M. A. Reimus

N. M. Sherer/A. H. McMakin

J. L. Straalsund

J. L. Swanson (20)

P. C. Walkup

Publishing Coordination (2)

Technical Information (5)

R. N. Gurley

J. M. Henderson

R. D. Prosser

K. R. Shah

R. J. Thompson

J. N. Appel

K. G. Carothers 